\title{
Thiol Disulfide Balance Oxidative Stress and Paraoxonase 1 Activities in Children and Adolescents Aged 6-16 Years with Specific Learning Disorders
}

\author{
Hasan Basri Savas ${ }^{1 \star}$, Ersin Sayar ${ }^{2}$, Tayfun Kara ${ }^{3}$
}

\begin{abstract}
${ }^{1}$ Alanya Alaaddin Keykubat University, Medical Faculty, Department of Medical Biochemistry, Antalya, TURKEY
${ }^{2}$ Istanbul Kanuni Sultan Suleyman Educational and Research Hospital, Department of Pediatric Gastroenterology, Istanbul, TURKEY

${ }^{3}$ Alanya Alaaddin Keykubat University, Medical Faculty, Department of Child and Adolescent Psychiatry, Antalya, TURKEY

*Corresponding Author: hasan.savas@alanya.edu.tr
\end{abstract}

Citation: Savas HB, Sayar E, Kara T. Thiol Disulfide Balance Oxidative Stress and Paraoxonase 1 Activities in Children and Adolescents Aged 6-16 Years with Specific Learning Disorders. Electron J Gen Med. 2021;18(3):em290. https://doi.org/10.29333/ejgm/10837

\section{ARTICLE INFO}

Received: 1 Jan. 2021

Accepted: 28 Feb. 2021

\begin{abstract}
Introduction: Specific learning disorders (SLD) are some of the most common neurodevelopmental disorders. The aim of this study is to determine the potential relationship between children with SLD and zinc, copper, paraoxonase 1 (PON1), arylesterase (ARY), ischemia-modified albumin, thiol balance, oxidative stress index, total antioxidant status, total oxidant status, and routine biochemical parameters.
\end{abstract}

Methods: All participants were assessed with the Kiddie Schedule for Affective Disorders and Schizophrenia for School-Age Children. Total oxidant status, total antioxidant status, thiol balance, ischemia modified albumin, paraoxonase 1 activity, arylesterase activity, zinc and copper levels were measured by the spectrophotometric methods.

Results: Compared to the control, the SLD group had statistically significantly lower values for PON1 antioxidant enzyme activity $(p=.045)$, ARY antioxidant enzyme activity $(p<.001), 25 \mathrm{OH}$ Vitamin $\mathrm{D}(\mathrm{p}=.005)$, reduced thiol ratio $(p=.028)$, thiol oxidation reduction ratio $(p=.01)$, native thiols $(p=.024)$ and significantly higher values for total oxidant status $(p=.017)$, oxidized thiol ratio $(p=.028)$.

Conclusion: The relationship between oxidative stress and SLD diagnosis in our results will be very important if it is supported by further new studies. In this case, evaluation of vitamin D, oxidative stress, antioxidant status and thiol balance may come to the agenda in the diagnosis and treatment of SLD.

Keywords: specific learning disorders, oxidant status, antioxidant status, $25 \mathrm{OH}$ vitamin D, zinc, copper

\section{INTRODUCTION}

Specific learning disorders (SLD) are some of the most common neurodevelopmental disorders. They refer to problems that continue in one of three areas: reading, writing and mathematics, and they form the basis of one's learning ability. SLD is a neurodevelopmental disorder that comes to the forefront in children at school age. The prevalence of SLD in school-aged children was reported to be in the range of 5$15 \%$ [1-3]. SLD has a multifactorial etiology including environmental factors, neuropsychological factors and genetic factors [4]. Studies have shown that children with learning difficulties are exposed to toxic metals, especially $\mathrm{Pb}, \mathrm{Al}$ and $\mathrm{Ni}$. Additionally, most of these children had low performance scores in cognitive ability tests in comparison to their healthy peers [5]. It was reported that zinc deficiency in childhood may cause delays in mental and physical development and lead to formation of learning difficulties [6]. It is known that memory and learning function is at stake because hippocampus and frontal cortex are injured by copper directly or through oxidative stress [7]. It is known that the role of oxidative stress in toxicological mechanisms due to metal exposure is one of the most significant mechanisms [5]. In animal experiments, it was found that oxidative damage in the cerebral cortex and hippocampus may contribute to a lack of cognitive functions and learning [8]. On the other hand, there is not any research in the literature, that evaluates some oxidative stress parameters in children and their relationship with SLD. Our aim of study is to determine the potential relationship between children with SLD and zinc, copper, paraoxonase 1, arylesterase, ischemiamodified albumin, thiol balance, oxidative stress index, total antioxidant status, total oxidant status, and routine biochemical parameters.

\section{METHODS}

\section{Study Design}

The study involved 44 children and adolescents aged between 6 and 16. All participants in the case group $(n=22)$ had a diagnosis of a specific learning disorder based on psychometric tests and psychiatric evaluation. Patients with psychiatric diseases other than SLD and those with any organic 
disease were excluded from the study. Healthy children who were not diagnosed with any psychiatric disorder constituted the control group $(n=22)$. First, 45 children diagnosed with SLD were included in the study, but 23 of these children were excluded because of comorbid psychiatric disorders. 8 of these children had more than one comorbid diagnosis. Attention deficit hyperactivity disorder (ADHD) was the most common comorbid diagnosis with 18 cases. The Kiddie Schedule for Affective Disorders and Schizophrenia for School-Age Children [6-18 ages] (K-SADS PL) was based on for assessment of individual participants [13]. K-SADS-PL is essential for identification of children and adolescents' current and lifelong psychopathology. When positive symptoms are described using a screening interview, another group of symptoms is used to further evaluate psychopathology. Gökler et al. conducted a survey for validity and reliability of the scale in Turkey [14]. As for its DSM-5 version translated into Turkish Ünal et al. studied the validity and reliability [15]. The participants were psychiatrically examined for diagnostic purpose other than this evaluation, in accordance with the Diagnostic and Statistical Manual of Mental Disorders, Fifth Edition (DSM-5) [16].

The Wechsler Intelligence Scale for Children-IV (WISC-IV) was used for the intelligence levels of the participants. WISC-IV was developed to measure the cognitive abilities of children of 6 and 16 years old [17]. The scale includes 10 basic and 5 substitute subtests that have been validated with psychometric measurements. As a result of the scale, five separate combined scores are obtained, namely the Verbal Concept Converted Score (VCCS), Perceptual Reason Converted Score (PRCS), Working Memory Transformed Score (VMTS), Transaction Speed Transformed Score (TSTS) and All Scale Intelligence Score (ASIS). The scale was adapted to Turkish in 2011 by Uluç et al. [18].

\section{Ethical Aspects}

The study was carried out with the approval dated 29.03.2019 and numbered 10354421-2019 / 5 from ALKU Clinical Research Ethics Committee. The parents of the minor patients read and signed the informed consent form. During the clinical trial, the Declaration of Helsinki was followed for ethical principles.

\section{Laboratory Analysis}

Blood samples collected into gel biochemistry tubes were centrifuged at $4000 \mathrm{~g}$ for 10 minutes in a cooled manner. The serum that was obtained was portioned in Eppendorf tubes. Serums frozen at $-80 \mathrm{C}^{\circ}$ in a laboratory-type freezer were thawed at room temperature upon completion of the samples. They were then mixed with a vortex device. Then, using commercial kits, total antioxidant status, total oxidant status, thiol balance, ischemia modified albumin, paraoxonase 1 activity, arylesterase activity, zinc and copper levels were measured with commercial kits (Rel Assay Diagnostics, Turkey). Wavelength measurements and concentration calculation according to standards were made in a microplate reader device (Biotek Synergy H1, USA). Reduced thiol ratio, oxidized thiol ratio, thiol oxidation reduction ratio, disulfide and oxidative stress index were calculated according to the literature $\left(\right.$ Reduced Thiol $=($ Native Thiol $/$ Total Thiol $){ }^{*} 100$. Oxidized Thiol $=($ Disulfide $/$ Total Thiol $){ }^{*} 100$. Thiol Oxidation Reduction Ratio $=($ Native Thiol $/$ Disulfide $) * 100$. Units: Disulfide levels ( $\mu \mathrm{mol} / \mathrm{l})$. Total thiol $(\mu \mathrm{mol} / \mathrm{l}) / \mathrm{alb}(\mathrm{g} / \mathrm{l})$. Native thiol ( $\mu \mathrm{mol} / \mathrm{L}) /$ alb (g / l). Disulfide ( $\mu \mathrm{mol} / \mathrm{l}) /$ alb (g / l). Oxidative stress index $=$ total oxidant status $/$ total antioxidant status) [19-27]. The results of hemogram and Vitamin B12, 25 $\mathrm{OH} \mathrm{D}$ levels were retrospectively taken from their files. B12 and $25 \mathrm{OH}$ vitamin D levels were measured on a Siemens Advia Centaur XPT automated analyzer using commercial kits (Siemens Healthcare Diagnostics Muenchen, Germany). Blood cells were counted in the hemogram autoanalyzer device. Sysmex branded reactives and Sysmex XN-1000 hematology autoanalyzer device (Sysmex Corporation, Kobe, Japan) were used.

\section{Statistical Analysis}

Categorical variables were assigned with calculated frequencies and percentages, and the continuous ones with mean, standard deviation and median values. The appropriate method for identification of the normal distribution of the continuous variables was Kolmogorov Smirnov test. Significance level was statistically defined as $p<0.05$. Intergroup comparative analysis of the laboratory results was achieved with ANOVA. Number Cruncher Statistical System, NCSS 11 (2016) was a statistical analytical package program that we utilized in our analysis.

\section{RESULTS}

Distribution of SLD patients by types were reading disorder (RD): 4, arithmetic disorder (AD): 2, spelling disorder (SD): 3, combined learning disorders (CD): 13 . the scores of WISC-IV of the participants were verbal comprehension: mean + SD: 91.16 + 13.84; perceptual reasoning: mean + SD: $90.41+11.47$; working memory: mean + SD: $93.25+6.28$; processing speed: mean + SD: $90.92+12.72$; total scale score mean + SD: $88.58+$ 9.56 .

Compared to the control, the SLD group had statistically significantly lower values for PON1 antioxidant enzyme activity $(p=.045)$, ARY antioxidant enzyme activity $(p<.001), 25 \mathrm{OH}$ Vitamin $D(p=.005)$, reduced thiol ratio $(p=.028)$, thiol oxidation reduction rate $(p=.01)$, native thiols $(p=.024)$ and significantly higher values for total oxidant status $(p=.017)$, oxidized thiol ratio $(p=.028)$. Both were indifferent based on the statistical significance level ( $p>.05)$ for the other parameters. Table 1 presents the sociodemographic data of children diagnosed with specific learning disorders. The detailed results of the comparison between the groups are given in Table 2. ROC Curve of statistically significant laboratory parameters were given in Figure 1. Area under the ROC Curve for statistically significant laboratory parameters were given in Table 3. graph:

ROC (Reciever Operator Characteristics Curve) analysis and

The important thing in evaluating ROC curves is the area under the curve (AUC-Area Under The Curve). The closer this area gets to 1 , the success of the model for using the relevant laboratory parameter in the diagnosis of the disease increases. The more hyperbolic the ROC analysis curve of a parameter and the greater the angle with the x-axis, the more meaningful it becomes. 
Table 1. Sociodemographic Data of Children Diagnosed with Specific Learning Disorders

\begin{tabular}{|c|c|}
\hline Parameters & Distribution \\
\hline Sex & Male: 14 (63.64\%) / Female: 8 (36.36\%). \\
\hline Age & $8.41 \pm 1.56$ \\
\hline Number of siblings & $2.77 \pm 1.11$ \\
\hline Sibling order & $2.09 \pm 1.23$ \\
\hline Dominant hand & Right: 17 (77.27\%) / Left: 5 (22.73\%). \\
\hline Dominant foot & Right: 16 (72.73\%) / Left: 6 (27.27\%). \\
\hline Dominant eye & Right: 15 (68.18\%) / Left: 7 (31.82\%). \\
\hline Severity of Specific Learning Disability & Mild: 3 (13.64\%) / Moderate: 11 (50\%) / Severe: 8 (36.36\%). \\
\hline Specific Learning Disability in Family & Yes: 10 (45.45\%) / No: 12 (54.55\%). \\
\hline Speech delay in the child & Yes: 12 (54.55\%) / No: 10 (45.45\%). \\
\hline Speech delay in family & Yes: 11 (50\%) / No: 11 (50\%). \\
\hline Mother's age & $35.64 \pm 5.19$ \\
\hline Mother's occupation & Not employed: 21 (95.45\%) / Corporate: 1 (4.55\%). \\
\hline Mother's education & Literate: 1 (4.55\%) / Primary education: 19 (86.36\%) / University and higher: 2 (9.09\%). \\
\hline Father's age & $39.59 \pm 6.58$ \\
\hline Fathers' occupation & Corporate: 2 (9.09\%) / Freelance: 20 (90.91\%). \\
\hline Father's education & Literate: 1 (4.55\%) / Primary education: 18 (81.82\%) / University and higher: 3 (13.63\%). \\
\hline Monthly income status & $\begin{array}{l}0-2 \text { thousand; } 3(13.64 \%), \\
2-4 \text { thousand; } 16(72.72 \%), \\
4-6 \text { thousand; } 2(9.09 \%), \\
6 \text { thousand and higher; } 1(4.55 \%) \text {. }\end{array}$ \\
\hline
\end{tabular}

The sociodemographic data of the 22 children at the ages of $6-16$ with specific learning disorders are shown in the table

Table 2. Evaluation of Biochemical Parameters in Children with Specific Learning Disorders

\begin{tabular}{|c|c|c|c|c|}
\hline Parameters & Unit & $\begin{array}{l}\text { Control Group } \\
(n=22) \text { mean } \pm S D\end{array}$ & $\begin{array}{l}\text { Specific Learning Disorders Group } \\
(n=22) \text { mean } \pm S D\end{array}$ & $\mathbf{p}$ \\
\hline Lymphocytes & cells per microliter of blood & $3250.91 \pm 1421.43$ & $2993.64 \pm 793.60$ & 0.463 \\
\hline Neutrophils & cells per microliter of blood & $3345.91 \pm 1141.43$ & $3885.91 \pm 1529.92$ & 0.192 \\
\hline Neutrophils/Lymphocytes & Ratio & $1.27 \pm 0.72$ & $1.38 \pm 0.67$ & 0.581 \\
\hline Leukocytes & cells per microliter of blood & $7515.91 \pm 1455.85$ & $7888.18 \pm 1918.26$ & 0.472 \\
\hline Vitamin B12 & $\mathrm{pg} / \mathrm{ml}$ & $465.86 \pm 128.93$ & $434.36 \pm 179.23$ & 0.507 \\
\hline $25 \mathrm{OH}$ Vitamin D & $\mathrm{ng} / \mathrm{ml}$ & $24.36 \pm 6.69$ & $18.64 \pm 6.18^{*}$ & 0.005 \\
\hline Paraoxonase 1 & $\mathrm{U} / \mathrm{l}$ & $665.05 \pm 101.60$ & $607.23 \pm 82.77^{*}$ & 0.045 \\
\hline Arylesterase & $\mathrm{U} / \mathrm{l}$ & $824.41 \pm 91.61$ & $667.82 \pm 73.99$ * & $<0.001$ \\
\hline Total Antioxidant Status & mmol Trolox equivalent/l & $1.35 \pm 0.23$ & $1.34 \pm 0.21$ & 0.874 \\
\hline Total Oxidant Status & $\mu \mathrm{mol} \mathrm{H}_{2} \mathrm{O}_{2}$ equivalent/l & $3.10 \pm 1.46$ & $3.94 \pm 0.63$ * & 0.017 \\
\hline Oxidative Stress Index & Ratio & $2.41 \pm 1.37$ & $3.00 \pm 0.68$ & 0.077 \\
\hline Total Thiol & $\mu \mathrm{mol} / \mathrm{l}$ & $337.11 \pm 22.39$ & $330.17 \pm 47.01$ & 0.535 \\
\hline Native Thiol & $\mu \mathrm{mol} / \mathrm{l}$ & $280.49 \pm 27.15$ & $257.13 \pm 38.22$ * & 0.024 \\
\hline Disulfide & $\mu \mathrm{mol} / \mathrm{l}$ & $28.30 \pm 15.43$ & $36.52 \pm 14.32$ & 0.074 \\
\hline Reduced Thiol Ratio & Ratio & $83.45 \pm 8.47$ & $78.09 \pm 7.07^{*}$ & 0.028 \\
\hline Oxidized Thiol Ratio & Ratio & $8.27 \pm 4.23$ & $10.96 \pm 3.53^{*}$ & 0.028 \\
\hline Thiol Oxidation Reduction Ratio & Ratio & $1295.28 \pm 636.68$ & $844.93 \pm 462.89$ * & 0.01 \\
\hline Ischemia modified albumin & $\mathrm{g} / \mathrm{l}$ & $1.03 \pm 0.22$ & $1.07 \pm 0.14$ & 0.447 \\
\hline Zinc & $\mu \mathrm{g} / \mathrm{dl}$ & $84.56 \pm 42.95$ & $99.89 \pm 41.09$ & 0.233 \\
\hline Copper & $\mu \mathrm{g} / \mathrm{dl}$ & $107.52 \pm 30.64$ & $113.76 \pm 26.31$ & 0.472 \\
\hline
\end{tabular}

Table 3. Area Under the ROC Curve for Statistically Significant Laboratory Parameters

\begin{tabular}{|c|c|c|c|c|c|}
\hline \multirow{3}{*}{ Test Result Variable(s) } & \multicolumn{3}{|c|}{ Area Under the Curve } & \multirow{2}{*}{\multicolumn{2}{|c|}{ Asymptotic $95 \%$ Confidence Interval }} \\
\hline & \multirow{2}{*}{ Area } & \multirow{2}{*}{ Std. Error ${ }^{a}$} & \multirow{2}{*}{ Asymptotic Sig. ${ }^{b}$} & & \\
\hline & & & & Lower Bound & Upper Bound \\
\hline $25 \mathrm{OH}$ Vitamin D (ng/ml) & .262 & .075 & .007 & .116 & .409 \\
\hline Paraoxonase $1(\mathrm{U} / \mathrm{I})$ & .301 & .086 & .024 & .131 & .470 \\
\hline Arylesterase (U/l) & .133 & .064 & .000 & .008 & .258 \\
\hline Total Oxidant Status $\left(\mu \mathrm{mol} \mathrm{H}_{2} \mathrm{O}_{2}\right.$ equivalent/l) & .692 & .086 & .029 & .523 & .861 \\
\hline Native Thiol $(\mu \mathrm{mol} / \mathrm{l})$ & .310 & .080 & .031 & .152 & .468 \\
\hline Reduced Thiol (Ratio) & .298 & .083 & .021 & .134 & .461 \\
\hline Oxidized Thiol (Ratio) & .699 & .083 & .024 & .537 & .862 \\
\hline Thiol Oxid. Red. Ratio (Ratio) & .298 & .083 & .021 & .134 & .461 \\
\hline
\end{tabular}

The test result variable(s): $25 \mathrm{OH}$ Vitamin D, Paraoxonase 1, Arylesterase, Reduced Thiol, Oxidized Thiol has at least one tie between the positive actual state group and the negative actual state group. Statistics may be biased.

a. Under the nonparametric assumption

b. Null hypothesis: true area $=0.5$ 


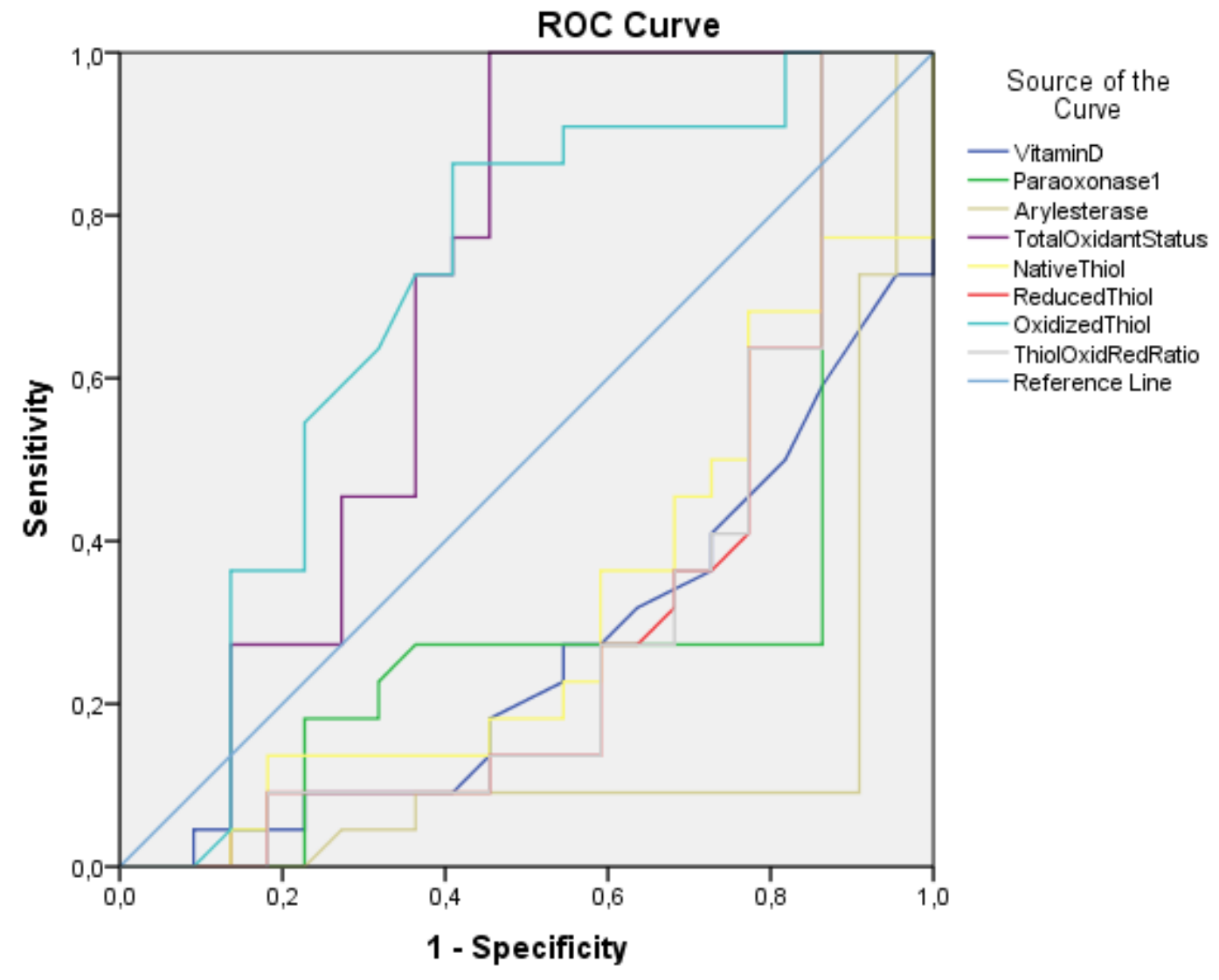

Diagonal segments are produced by ties.

Figure 1. ROC Curve of Statistically Significant Laboratory Parameters

ROC (Receiver Operator Characteristics Curve) analysis and graph:

The important thing in evaluating ROC curves is the area under the curve (AUC-Area Under The Curve). The closer this area gets to 1 , the success of the model for using the relevant laboratory parameter in the diagnosis of the disease increases. The more hyperbolic the ROC analysis curve of a parameter and the greater the angle with the $\mathrm{x}$-axis, the more meaningful it becomes

\section{DISCUSSION}

The incidence of SLD in childhood was found to be in the range of $5-15 \%$ [3]. To date, sufficient molecular and biochemical evidence for the etiology of SLD has not been revealed. Disruption of the balance between the oxidative status and the antioxidant status may lead to widespread oxidative damage in all tissues and organs and create many serious disease tables. Indeed, oxidative stress was accused of myelin deficiency and also learning dysfunction $[28,29]$. On the other hand there is not any research in the literature, that evaluates some oxidative stress parameters in children and their relationship with SLD. For this reason, we aimed to study the antioxidant and oxidant status, as well as other related laboratory parameters in children with SLD.

Despite all the searches we have done in the literature, no concrete research and findings have been reached on specific learning disorders regarding paraoxonase 1, arylesterase activities, native thiol and total thiol, ischemia modified albumin, total oxidant status, and total antioxidant status levels. For this reason, although there is a deficiency in the discussion part of our article, the original value of the article and its potential to be a source for new researches is very high. Displaying clinical laboratory parameters that may be associated with specific learning disorders may be very important for clarifying the etiology, investigating other related mechanisms, diagnosis, and treatment follow-up. Although there are no articles that can be similar to the measured parameters in our study, a limited number of studies including other parameters that may indicate oxidant and antioxidant status are discussed below.

In the light of the literature, we have seen that differences in metal levels may have both direct and oxidative stressrelated effects and influence cognitive functions. It is known that maintaining a healthy diet and using vitamins are important for reducing the risk of cognitive impairment [9]. Although it has been claimed that people with learning difficulties have a higher risk of vitamin D deficiency in comparison to the general population, there are other publications that claim otherwise $[10,11]$. Vitamin B-12 is essential for brain development, as well as neural and cognitive function. It is known that inadequate vitamin B-12 levels in early childhood cause cognitive development disorders [12].

Looking at our findings, in the SLD group, the total oxidant status ( $p=.017)$, antioxidant enzymes PON1 $(p=.045)$ and ARY $(p<.001)$ levels significantly decreased relatively to the control. Additionally, when the thiol balance was evaluated, the SLD group was significantly different from the control, with lower values for reduced thiol ratio $(p=.028)$, thiol oxidation reduction ratio $(p=.01)$ and native thiols $(p=.024)$ and with 
higher values for oxidized thiol level $(p=.028)$. The Oxidative Stress Index (OSI) value can be found by proportioning the serum Total Oxidant Level (TOS) value to the serum Total Antioxidant Level (TAS) value. The increase in antioxidant capacity in response to the increase in oxidative stress may mislead the measurement of TOS only in terms of causing oxidative damage, cell, tissue, and organ damage. By comparing the change in the TOS / TAS ratio, an accurate comparison is possible by eliminating the potentially misleading antioxidant reactive response for oxidative damage [21-23]. Thanks to TAS, TOS and OSI values, information and interpretation can be made about the oxidant-antioxidant capacity status, which is known to have a role in the etiology of many diseases, including pathologies with neurological and central nervous system involvement [21]. The antioxidant system with many components and the general evaluation of oxidative stress makes TAS, TOS measurement useful. For this reason, it is an important finding in our study that the OSI values are numerically higher in the SLD group and that this high OSI value is close to the statistically significant limit. In new clinical studies to be conducted by increasing the sample size, it is likely that a statistically significant value will occur in terms of OSI. Thiol contains a sulfhydryl group and is very effective in preventing oxidative stress. Reactive oxygen species oxidize thiol groups to form disulfide bonds. The dynamic thiol balance indicates the balance between thiol and disulfide. Maintaining this balance is very important in regulation of antioxidant capacity, detoxification, apoptosis, signal transduction and enzyme activities. Thiol oxidation produces reversible disulfide bonds, and if reduced, they may turn back into thiol bonds. Disruption of the balance between thiol and disulfide has been associated with the occurrence of many serious diseases. The thiol-disulfide balance may account for neurological disorders such as Parkinson's, Alzheimer's and Multiple Sclerosis [30,31]. No data related to the relationship between the thiol balance and SLD have been found in the literature. Based on our results, it was observed that such a balance was significantly impaired in oxidation in children with SLD. There is a possible relationship between zinc and copper levels and neurological disorders. For this reason, the changes in the zinc and copper levels in children with SLD were examined. No significant difference in the zinc and copper values between the groups may be interpreted as there was no significant relationship between SLD and zinc and copper levels. In our measurements, the fact that vitamin D levels significantly declined for the SLD patient children differently from the control group ( $p=.005$ ) suggested that vitamin $D$ deficiency is included in the etiology of SLD. In this case, as a result of oxidative stress increase not being balanced with antioxidant capacity increase, it may be thought that damage to the central nervous system may be associated with SLD [8]. There is a statistically significant difference between control and specific learning disorders groups for paraoxonase 1 , arylesterase, total antioxidant status, native thiol, reduced thiol ratio, oxidized thiol ratio, thiol oxidation reduction ratio values $(p<0.05)$. In this case, it can be thought that there is a relationship between the occurrence of specific learning disorders and increased oxidative stress and reduced antioxidant capacity. The disruption of the balance between oxidative stress and antioxidant capacity in the direction of oxidative stress leads to an increase in free oxygen radicals. One of the most important effects of free radical increase is that it leads to lipid peroxidation [32,33]. In lipid peroxidation, unsaturated fatty acids are oxidized. Lipid peroxides complete their chemical transformation by transforming into aldehyde and other carbonyl compounds. As a result, the structure and functions of lipids are affected. In addition, aldehyde formed as a result of lipid peroxidation has a cytotoxic effect. Increase of free radicals can also result in protein oxidation and DNA structure degradation. In various studies conducted on experimental animals, it has been shown that the increase in free oxygen radicals increases lipid peroxidation in the brain tissue and leads to neurodegeneration [34-36].

In our study, paraoxonase 1, arylesterase, total antioxidant status, native thiol, reduced thiol ratio, oxidized thiol ratio, thiol oxidation reduction ratio values can lead to neurodegeneration with structural and functional disorders caused by the increase in lipid peroxidation in central nervous system tissues with very high lipid content and oxygen use and as a result it may have led to specific learning disorders. The general literature information regarding the fact that oxidative stress increase leads to learning disability supports our research results [7]. The $1,25(\mathrm{OH})_{2} \mathrm{D}_{3}$ which is active form of Vitamin $D$ regulates the expression and functioning of a range of brain-specific proteins, neurotransmitter turnover, neurogenesis and neuroplasticity [37]. For this reason, the lower $25 \mathrm{OH}$ vitamin D levels in the specific learning disorders group in our findings compared to the control group can be explained by the literature.

Studies in the literature have shown that increased oxidative stress can cause tissue and organ damage [38-40]. The results of our study showing that measuring new parameters that may be indicators of oxidative stress and antioxidant system may be significant in children with SLD are valuable for these reasons.

\section{CONCLUSION}

In case of specific learning disorders, oxidative stress, antioxidant status and $25 \mathrm{OH}$ vitamin D deficiency may be considered. The comparability of increasing oxidative stress and $25 \mathrm{OH}$ vitamin D deficiency with SLD diagnosis in our results may be very important if it is supported by further experimental and clinical studies. In literature, there is limited research and evidence on the likely association between SLD and oxidative stress, antioxidant status, antioxidant enzymes and the thiol balance and $25 \mathrm{OH}$ vitamin D. Our results are very specific in this respect.

\section{HIGHLIGHTS}

According to the research results in this paper it was determined that:

- The deterioration resulting from oxidation in nativetotal thiol balance may be a laboratory indicator for pediatric specific learning disorders patients.

- Paraoxonase 1 , arylesterase, which is the indicator of the antioxidant status are lower in pediatric specific learning disorders patients.

- Vitamin D deficiency may be considered as a laboratory indicator in pediatric specific learning disorders patients.

- The deterioration resulting from oxidation in total oxidant status may be a laboratory indicator for pediatric specific learning disorders patients. 
Author contributions: All authors have sufficiently contributed to the study, and agreed with the results and conclusions.

Funding: During this study, no financial or spiritual support was received neither from any pharmaceutical company that has a direct connection with the research subject, nor from a company that provides or produces medical instruments and materials which may negatively affect the evaluation process of this study.

Protection of humans: The authors declare that the procedures were followed according to the regulations established by the Clinical Research and Ethics Committee and to the 2013 Helsinki Declaration of the World Medical Association.

Declaration of interest: No conflicts of interest between the authors and / or family members of the scientific and medical committee members or members of the potential conflicts of interest, counseling expertise, working conditions, shareholding and similar situations in any firm.

Data confidentiality: The authors declare having followed the protocols in use at their working center regarding patients' data publication.

\section{REFERENCES}

1. American Psychiatric Association (APA). Diagnostic and Statistical Manual of Mental Disorders (DSM-5R), Washington DC: American Psychiatric Association, 2013. https://doi.org/10.1176/appi.books.9780890425596

2. Schulte-Körne G. Spezifische lernstörungen [Specific learning disabilities - from DSM-IV to DSM-5]. Z Kinder Jugendpsychiatr Psychother. 2014;42(5):369-74. https://doi.org/10.1024/1422-4917/a000312 PMid:25163999

3. Shah HR, Sagar JKV, Somaiya MP, Nagpal JK. Clinical Practice Guidelines on Assessment and Management of Specific Learning Disorders. Indian J Psychiatry. 2019; 61(Suppl 2):211-25. https://doi.org/10.4103/psychiatry.Indi anJPsychiatry_564_18 PMid:30745697 PMCid:PMC6345134

4. Pham AV, Riviere A. Specific Learning Disorders and ADHD: Current Issues in Diagnosis Across Clinical and Educational Settings. Curr Psychiatry Rep. 2015;17(6):38. https://doi.org/10.1007/s11920-015-0584-y PMid:25894357

5. do Nascimento SN, Charão MF, Moro AM, Roehrs M, Paniz C, Baierle M, et al. Evaluation of toxic metals and essential elements in children with learning disabilities from a rural area of southern Brazil. Int J Environ Res Public Health. 2014;17;11(10):10806-23. https://doi.org/10.3390/ijerph11 1010806 PMid:25329533 PMCid:PMC4211007

6. Kawahara M, Tanaka KI, Kato-Negishi M. Zinc, Carnosine, and Neurodegenerative Diseases. Nutrients. 2018;10(2): 147. https://doi.org/10.3390/nu10020147 PMid:29382141 PMCid:PMC5852723

7. Kalita J, Kumar V, Misra UK, Bora HK. Memory and Learning Dysfunction Following Copper Toxicity: Biochemical and Immunohistochemical Basis. Mol Neurobiol. 2018;55(5):3800-11. https://doi.org/10.1007/s12035-0170619-y

8. Fukui K, Omoi NO, Hayasaka T, Shinnkai T, Suzuki S, Abe K, et al. Cognitive impairment of rats caused by oxidative stress and aging, and its prevention by vitamin $\mathrm{E}$. Ann N Y Acad Sci. 2002;959:275-84. https://doi.org/10.1111/j.17496632.2002.tb02099.x PMid:11976202
9. Qin B, Xun P, Jacobs DR Jr, Zhu N, Daviglus ML, Reis JP, et al. Intake of niacin, folate, vitamin B-6, and vitamin B-12 through young adulthood and cognitive function in midlife: the Coronary Artery Risk Development in Young Adults (CARDIA) study. Am J Clin Nutr. 2017;106(4):1032-40. https://doi.org/10.3945/ajcn.117.157834 PMid:28768650 PMCid:PMC5611785

10. Walton, C, Isaac, A, Kerr, M. Prevalence of vitamin D deficiency in people with learning disability: A systematic review. $\mathrm{Br} \mathrm{J}$ Learn Disabil. 2019;47: 279-88. https://doi.org/10.1111/bld.12285

11. Frighi V, Morovat A, Stephenson MT, White SJ, Hammond CV, Goodwin GM. Vitamin D deficiency in patients with intellectual disabilities: prevalence, risk factors and management strategies. Br J Psychiatry. 2014;205(6):45864. https://doi.org/10.1192/bjp.bp.113.143511 PMid: 25257061

12. Venkatramanan S, Armata IE, Strupp BJ, Finkelstein JL. Vitamin B-12 and Cognition in Children. Adv Nutr. 2016;7(5):879-88. https://doi.org/10.3945/an.115.012021 PMid:27633104 PMCid:PMC5015033

13. Kaufman J, Birmaher B, Brent D, Rao U, Flynn C, Moreci P, et al. Schedule for Affective Disorders and Schizophrenia for School-Age Children-Present and Lifetime Version (KSADSPL): initial reliability and validity data, J Am Acad Child Adolesc Psychiatry. 1997;36:980-8. https://doi.org/ 10.1097/00004583-199707000-00021 PMid:9204677

14. Gökler B, Ünal F, Pehlivantürk B, Çengel-Kültür E, Akdemir D, Taner Y. Okul Çağı Çocukları için Duygulanım Bozuklukları ve Şizofreni Görüşme Çizelgesi-Şimdi ve Yaşam Boyu Şekli-Türkçe Uyarlamasının Geçerlik ve Güvenirliği. [Affective Disorders and Schizophrenia Interview Schedule for School Age Children-Now and Lifelong Form-Validity and Reliability of Turkish Adaptation, Journal of Child and Youth Mental Health]. Çocuk ve Gençlik Ruh Sağlığı Dergisi. 2004;11:109-16.

15. Ünal F, Öktem F, Çetin Çuhadaroğlu F, Çengel Kültür SE, Akdemir D, Foto Özdemir D, et al. Okul Çağı Çocukları için Duygulanım Bozuklukları ve Şizofreni Görüşme ÇizelgesiŞimdi ve Yaşam Boyu Şekli-DSM-5 Kasım 2016 -Türkçe Uyarlamasının (ÇDŞG-ŞY-DSM-5-T) Geçerlik ve Güvenirliği. [Affective Disorders and Schizophrenia Interview Schedule for School Age Children - Now and Lifelong Form - DSM - 5 November 2016 - Validity and Reliability of Turkish Adaptation (ÇDŞG - ŞY - DSM - 5 - T). Turk Psychiatry Journal]. Turk Psikiyatri Derg. 2019;30:42-50.

16. Diagnostic and Statistical Manual of Mental Disorders, Fifth Edition. (DSM-5) American Psychiatric Association. American Psychiatric Association Publishing. 2013.

17. Wechsler, D. Wechsler Intelligence Scale for ChildrenFourth edition (WISC-IV). San Antonio, TX: Pearson. 2003. https://doi.org/10.1037/t15174-000

18. Uluç S, Öktem F, Erden G, Gençöz T, Sezgin N. Wechsler Çocuklar İçin Zekâ Ölçeği-IV: Klinik bağlamda zekânın değerlendirilmesinde Türkiye için yeni bir dönem. [Wechsler Intelligence Scale for Children-IV clinical context in a new era for Turkey in the evaluation of intelligence. Turkish Psychology Articles]. Türk Psikoloji Yazıları, 2011;14(28):49-57. 
19. Bednarz-Misa I, Berdowska I, Zboch M, Misiak B, Zieliński B, Płaczkowska $S$, et al. Paraoxonase 1 decline and lipid peroxidation rise reflect a degree of brain atrophy and vascular impairment in dementia. Adv Clin Exp Med. 2020;29(1):71-8. https://doi.org/10.17219/acem/111377 PMid:31967744

20. Ayan D, Şeneş M, Çaycı AB, Söylemez S, Eren N, Altuntaş Y, et al. Evaluation of Paraoxonase, Arylesterase, and Homocysteine Thiolactonase Activities in Patients with Diabetes and Incipient Diabetes Nephropathy. J Med Biochem. 2019;26;38(4):481-8. https://doi.org/10.2478/ jomb-2019-0014 PMid:31496913 PMCid:PMC6708292

21. Savran M, Aslankoc R, Ozmen O, Erzurumlu Y, Savas HB, Temel EN, et al. Agomelatine could prevent brain and cerebellum injury against LPS-induced neuroinflammation in rats. Cytokine. 2020;20;127:154957. https://doi.org/ 10.1016/j.cyto.2019.154957 PMid:31869757

22. Savran M, Asci H, Ozmen O, Erzurumlu Y, Savas HB, Sonmez $Y$, et al. Melatonin protects the heart and endothelium against high fructose corn syrup consumption-induced cardiovascular toxicity via SIRT-1 signaling. Hum Exp Toxicol. 2019;38(10):1212-23. https://doi.org/10.1177/ 0960327119860188 PMid:31256681

23. Cankara FN, Özmen Ö, Savaş HB, Şahin Y, Günaydın C. Gastroprotective effect of tarantula cubensis extract in the indomethacin-induced peptic ulcer model in rats. Acta Med. Alanya 2020;4(3):278-84. https://doi.org/10.30565/ medalanya. 797406

24. Erdem D, Savas HB, Erdem N, Kuloglu Genc S, Avcioglu G. Ischemia Modified Albumin as a New Marker for Diagnosis of Early Pregnancy Losses. Int J Acad Med Pharm. 2020;2(3):222-7. https://doi.org/10.29228/jamp.44816

25. Erel O, Neselioglu S. A novel and automated assay for thiol/disulphide homeostasis. Clin Biochem. 2014;47(18):326-32. https://doi.org/10.1016/j.clinbiochem. 2014.09.026 PMid:25304913

26. Homsher R, Zak B. Spectrophotometric Investigation of Sensitive Complexing Agents for the Determination of Zinc in Serum. Clin Chem. 1985;31(8):1310-3. https://doi.org/ 10.1093/clinchem/31.8.1310 PMid:4017236

27. El-Masry HMA, Sadek AA, Hassan MH, Ameen HH, Ahmed HA. Metabolic profile of oxidative stress and trace elements in febrile seizures among children. Metab Brain Dis. 2018;33(5):1509-15. https://doi.org/10.1007/s11011-018 0258-7 PMid:29946956

28. Xin W, Chan JR. Myelin plasticity: sculpting circuits in learning and memory. Nat Rev Neurosci. 2020;21(12):68294. https://doi.org/10.1038/s41583-020-00379-8 PMid: 33046886

29. Ravera S, Bartolucci M, Cuccarolo P, Litame E, Illarcio M, Calzia D, et al. Oxidative stressin myelin sheath: the other face of the extramitochondrial oxidative phosphorylation ability. Free Radic Res. 2015;49(9):1156-64. https://doi.org/ 10.3109/10715762.2015.1050962 PMid:25971447

30. Bektas H, Vural G, Gumusyayla S, Deniz O, Alisik M, Erel O. Dynamic thiol-disulfide homeostasis in acute ischemic stroke patients. Acta Neurol Belg. 2016;116:489-94. https://doi.org/10.1007/s13760-016-0598-1 PMid:26782823
31. Musumeci M, Sotgiu S, Persichilli S, Arru G, Angeletti S, Fois $\mathrm{ML}$, et al. Role of $\mathrm{SH}$ levels and markers of immune response in the stroke. Dis Markers. 2013;35(3):141-7. https://doi.org/10.1155/2013/246205 PMid:24167359 PMCid:PMC3774977

32. Gültekin F, Nazıroğlu M, Savaş HB, Çiğ B. Calorie restriction protects against apoptosis, mitochondrial oxidative stress and increased calcium signaling through inhibition of TRPV1 channel in the hippocampus and dorsal root ganglion of rats. Metab Brain Dis. 2018;33(5):1761-74. https://doi.org/10.1007/s11011-018-0289-0 PMid:30014177

33. Savas HB, Gultekin F, Ciris IM. Positive effects of meal frequency and calorie restriction on antioxidant systems in rats. North Clin Istanbul. 2017;4(2):109-16. https://doi.org/10.14744/nci.2017.21548 PMid:28971167 PMCid:PMC5613257

34. Lapi D, Stornaiuolo M, Sabatino L, Sommella E, Tenore G, Daglia M, et al. The Pomace Extract Taurisolo Protects Rat Brain From Ischemia-Reperfusion Injury. Front Cell Neurosci. 2020;14:3. https://doi.org/10.3389/fncel.2020. 00003 PMid:32063837 PMCid:PMC6997812

35. Tu LF, Cao LF, Zhang YH, Guo YL, Zhou YF, Lu WQ, et al. Sirt3-dependent deacetylation of COX-1 counteracts oxidative stress-induced cell apoptosis. FASEB J. 2019;33(12):14118-28.

https://doi.org/10.1096/fj.201900708R PMid:31647884

36. Joksimovic SM, Di Gruccio MR, Boscolo A, JevtovicTodorovic V, Todorovic SM. The Role of Free Oxygen Radicals in Lasting Hyperexcitability of Rat Subicular Neurons After Exposure to General Anesthesia During Brain Development. Mol Neurobiol. 2020;57(1):208-16. https://doi.org/10.1007/s12035-019-01770-y PMid:31493241 PMCid:PMC7273833

37. Kasatkina LA, Tarasenko AS, Krupko OO, Kuchmerovska TM, Lisakovska OO, Trikash IO. Vitamin D deficiency induces the excitation/inhibition brain imbalance and the proinflammatory shift. Int J Biochem Cell Biol. 2020;119:105665. https://doi.org/10.1016/j.biocel.2019. 105665 PMid:31821883

38. Seflek HN, Kalkan S, Cuce G, Kılınc I, Sozen ME. Effects of Nigella sativa oil on ovarian volume, oxidant systems, XIAP and NF-kB expression in an experimental model of diabetes. Biotech Histochem. 2019;94(5):325-33. https://doi.org/10.1080/10520295.2019.1566571 PMid:30821520

39. Cuce G, Canbaz HT, Sozen ME, Yerlikaya FH, Kalkan S. Vitamin $E$ and selenium treatment of monocrotaline induced hepatotoxicity in rats. Biotech Histochem. 2017;92(1):59-67. https://doi.org/10.1080/10520295.2016. 1267798 PMid:28166421

40. Savran M, Ozmen O, Erzurumlu Y, Savas HB, Asci S, Kaynak M. The Impact of Prophylactic Lacosamide on LPS-Induced Neuroinflammation in Aged Rats. Inflammation. 2019;42(5):1913-24. https://doi.org/10.1007/s10753-01901053-7 PMid:31267274 